\title{
Diagnostic Visualization of Changes in Biological Tissues by Ultrasound method Based on Doppler Effect
}

\author{
I.M. Lukavenko*, I.A. Symonenko
}

\author{
Sumy State University, 2, Rymsky-Korsakov St., 40007 Sumy, Ukraine
}

(Received 15 June 2021; revised manuscript received 09 August 2021; published online 20 August 2021)

\begin{abstract}
Physical processes of ultrasonic waves influence on biological tissues are studied. It is shown that the reflection and absorption of ultrasound by tissues depend on their structure, properties and frequency of ultrasonic waves. The absorption coefficient of ultrasound changes significantly when the structure and condition of the tissue change due to the development of a pathological process in it. Ultrasound with therapeutic effect on the tissue causes mechanical, thermal and physicochemical effects, the relationship between which depends on the intensity of action and external conditions. It is found that strong absorption of ultrasound is observed at the tissue boundaries that have different acoustic properties. The mechanisms of ultrasonic waves influence on soft biological tissues are considered. Based on sonograms obtained in ultrasound devices using the Doppler effect, the assessment of blood flow velocity in benign tumors is performed. It is obtained that the blood flow velocity in benign breast tumors has a value from 0.6 to $0.3 \mathrm{~cm} / \mathrm{s}$ (minimum value) and from 3.0 to $10.6 \mathrm{~cm} / \mathrm{s}$ (maximum value). It is proved that the method of color Doppler mapping in the diagnosis of tumors gives a completely reliable result in the case of cysts and an unreliable result in sclerosing adenosis.
\end{abstract}

Keywords: Ultrasonic waves, Doppler effect, Sonograms, Blood flow rate.

\section{INTRODUCTION}

At the present stage of micro- and nanoelectronics development, ultrasonic technologies are widely used in medicine [1,2], control and measuring equipment, sensor technology (see, for example, [3]).

Ultrasound diagnostics (USD, sonography, ultrasonography) is a method of radiation diagnostics that uses high-frequency sound (ultrasound) waves to obtain an image of the internal organs of the human body. USD is widely used in clinical practice. Over the past few decades, the method has become one of the most widespread and important, which provides the diagnosis of many diseases. The technique has no contraindications, is safe, it is distinguished by a sufficiently high diagnostic efficiency (diagnostic accuracy for a number of diseases in comparison with pathological data reaches more than $80 \%$ ), simplicity, absence of radiation exposure, non-invasiveness, the possibility of multiple studies, as well as the fact that it is conducted in real time.

A significant advantage in comparison with other methods of radiation diagnostics is the cost-effectiveness of USD. Therefore, ultrasound can be used as a screening method for examining many organs and systems. At the same time, the ultrasonic method has some disadvantages:

- significant limitations in the study of a number of organs and systems (lungs, internal bone structure, the brain in adults);

- dependence of the resulting image quality on the apparatus class;

- subjectivity in the resulting image interpretation, i.e., the dependence of the diagnostic accuracy on the doctor qualifications;

- relatively low opportunities for documenting images.

The aim of the work was to study the properties of the ultrasonic waves influence on biological tissues in terms of visualization of pathological processes in them and to assess the blood flow velocity in benign tumors based on sonograms obtained by ultrasound devices using the Doppler effect.

\section{PHYSICAL BASIS OF ULTRASOUND DIAGNOSTICS}

Ultrasonic waves have certain properties that allow them to be used for diagnostics: they propagate in a straight line, therefore, it is possible to obtain images of the organs under study practically without distortion, while maintaining their linear dimensions and shape; they are able to focus; penetrate the organs; they are reflected in different ways from the boundaries of various densities of both the outer contours of biological tissues and their internal structure - they are able to carry certain information about the internal structure and functions of organs.

Ultrasound is sound vibrations with a frequency of more than $20 \mathrm{kHz}$. Frequency in the range from 25 to $500 \mathrm{kHz}$ is used by living organisms in nature - bats, dolphins and some breeds of whales. Like sound of the person's audible zone, ultrasound also propagates in media in the form of alternating zones of compression and rarefaction of molecules of a substance, which perform oscillatory movements (Fig. 1).
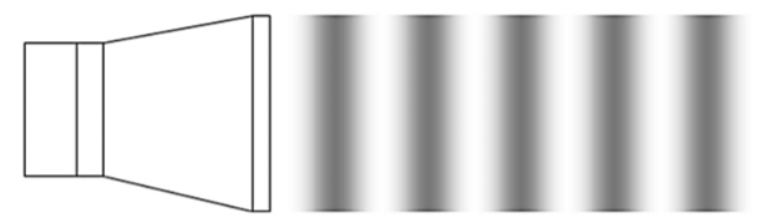

Fig. 1 - Scheme of ultrasonic wave propagation at the source that generates it

\footnotetext{
*i.lukavenko@med.sumdu.edu.ua
} 
The main characteristics of ultrasonic waves are the oscillation period $(T)$ - the time during which a molecule or particle of a substance makes one complete oscillation, frequency $(v)$ - the number of oscillations per unit time, length $(\lambda)$ - the distance between points of one phase, and propagation velocity $(c)$, which depends on the elasticity and density of the medium. Wavelength is inversely proportional to its frequency.

The ultrasonic propagation velocity is determined only by the properties of biological tissue, mainly by its density. The average ultrasonic velocity in the tissues of the human body is $1540 \mathrm{~m} / \mathrm{s}$ - most USD devices are programmed. When the ultrasonic wave propagates, energy is transmitted (wave intensity $I$ ). The intensity of the transmitted ultrasound gradually decreases as it passes through the biological tissues. The total loss of intensity is called attenuation and occurs through attenuation, absorption and scattering $[4,5]$.

The velocity of ultrasound through a tissue is largely determined by its elasticity. The density and elasticity of a tissue together determine its so-called acoustic impedance or impedance $(Z=\rho c$, where $Z$ is the acoustic impedance, $\rho$ is the density). The greater the difference in acoustic impedance, the greater the reflection of ultrasound [6]. An extremely large difference in acoustic impedance exists at the soft tissue/gas interface, and almost all ultrasound is reflected from it. This explains the use of a gel as an interlayer between the patient's skin and the transducer to eliminate air, which can completely block the ultrasonic wave.

In USD, a range of $2-15 \mathrm{MHz}$ is used. This range is due to the physical characteristics of ultrasound (the dependence of the scanning depth on the frequency) and diagnostic tasks of ultrasound (obtaining an image with as much resolution as possible). The ratios of the frequency and depth of penetration of ultrasound into soft tissues are approximately equal: $1 \mathrm{MHz}-$ up to $50 \mathrm{~cm}, 3.5 \mathrm{MHz}-30 \mathrm{~cm}, 5 \mathrm{MHz}-15 \mathrm{~cm}, 7.5 \mathrm{MHz}-$ $7 \mathrm{~cm}, 10 \mathrm{MHz}-5 \mathrm{~cm}[1,6]$.

The USD method allows obtaining not only information about the structural state of organs and tissues, but also characterizing the flows in the vessels. This ability is based on the Doppler effect - a change in the frequency of the received sound, when the sound source or receiver or a body, which scatters the sound, moves relative to the environment. It is observed due to the fact that the speed of propagation of sound (ultrasound) in any homogeneous medium is constant. By comparing the initial ultrasound frequency with the modified one, the Doppler shift can be determined, and the velocity can be calculated (estimated). In this case, the object must move away or approach the radiation source (in our case, to the sensor or from the sensor). If the object moves along the sensor, i.e., does not approach or recede, then it remains stationary or "invisible" for Doppler examination. Blood elements are used as a moving object when using the Doppler effect in medicine. Doppler modes allow assessing the main parameters of blood flow - velocity, direction, laminarity, as well as the degree of vascularization of the area under study.

Currently, the following types of Doppler studies are used in clinical practice: continuous and pulsed streaming spectral Doppler, color Doppler mapping, power Doppler, convergent color Doppler. Color Doppler mapping (color Doppler) is based on color coding of the Doppler shift of the radiated frequency. The technique provides direct visualization of blood flows in the heart and in relatively large vessels, allows obtaining two-dimensional information about blood flows in real time, in addition to conventional two-dimensional visualization. If the reflected signal has a frequency different from the radiated one, this means that it is reflected from a moving object. Typically, the direction of flow to the sensor is coded in red and from the sensor in blue. The brightness of the color is determined by the flow rate [7]. Dark shades of these colors correspond to low speeds, light shades to high speeds. Disadvantage: the impossibility of obtaining an image of small blood vessels with a low blood flow velocity. Advantages: allows you to assess both the morphological state of the vessels and the state of blood flow through them.

\section{VISUALIZATION OF EFFECTS IN BIOLOGICAL TISSUES: METHODS AND RESULTS}

For the visualization of changes in biological tissues by the ultrasound method, a portable ultrasound device of the Mindray DC-N3 type with high image quality and color Doppler is used. The device operates in dynamic mode (180 dB range) and automatically optimizes images. Scanning to be viewed in two-dimensional and triplex modes from linear multifrequency sensors; scan depth up to $30 \mathrm{~cm}$ and automatic analysis of Doppler curves.

Fig. 2 shows a scheme for measuring blood flow rate based on the Doppler effect in the pulse-wave mode. From the generator 1 of electrical oscillations of ultrasonic frequency, the signal goes to the ultrasound emitter 2 and to the frequency comparison device 3 . The ultrasound wave 4 penetrates into the blood vessel 5 and is reflected from the moving erythrocytes 6 . The reflected ultrasound wave 7 enters the receiver 8 , where it is converted into electrical oscillation and amplified. 9 - soft tissues, in the depth of which the vessel is located. The amplified electrical oscillation enters the device 3. Here, the oscillations corresponding to the incident and reflected waves are compared, and the Doppler frequency shift is distinguished in

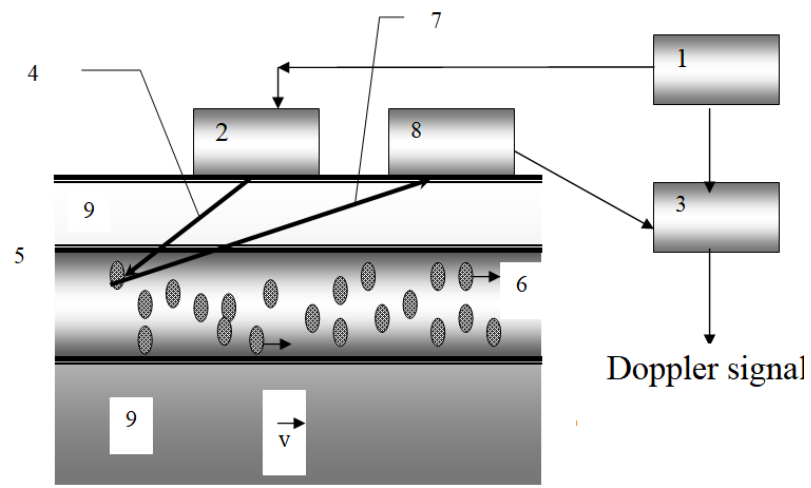

Fig. 2-Scheme to explain the Doppler effect method for estimating blood flow velocity: 1 - generator; 2 - emitter; 3 frequency comparison device; 4 - ultrasound wave; 5 -blood vessel; 6 - moving erythrocytes; 7 - reflected ultrasound wave; 8 - receiver; 9 - soft tissues 
the form of an electrical oscillation. In large vessels, the speed of erythrocytes is different depending on their location relative to the axis: "paraxial" erythrocytes move at a higher speed, and "parietal" ones - at a lower speed.

The ultrasound wave is reflected from different red blood cells, hence the Doppler shift is a frequency interval. Therefore, this method allows you to estimate the average blood flow velocity. The method based on the color selection of zones of pathological and normal blood flow from a general black-and-white image is called color Doppler blood flow mapping.

The method of color Doppler mapping allows you to estimate the blood flow velocity based on the original measurement data, such as the oscillation frequency and angle of sensor inclination relative to the blood vessel axis.

To estimate the blood flow velocity by Doppler frequency shift, it is necessary to approximately measure the angle $\alpha$ of sensor inclination relative to the axis of the blood vessel (Fig. 3). In the case when the axes of the sensor and the vessel are perpendicular to each other $\left(\alpha=90^{\circ}\right.$ and $\left.\cos \alpha=0\right)$, it is impossible to estimate the blood flow velocity, because the Doppler shift $F_{D}=0$. The value $F_{D}>0$ (Fig. $3 \mathrm{~b}$ ), when $\cos \alpha>0$, and if you tilt the sensor in the opposite direction (Fig. 3c), then $F_{D}<0 \quad(\cos \alpha<0)$. When observing blood flow in the vessels, it should be taken into account that the maximum value of the Doppler shift will be observed at angles $\alpha=30-45^{\circ}$.

When the angle increases above $155^{\circ}$ (the critical angle), ultrasound may not pass through the boundary between the vessel wall and the blood, but may be completely reflected from this boundary.

We carried out ultrasound examination of the mammary glands and lymph nodes of 65 women aged 16 to 78 years (mean age 47 years) both traditionally in grayscale mode and using color Doppler mapping with a 7.5-12 MHz wideband sensor. Absolutely all observations were verified histologically. The structure of benign formations: benign breast dysplasia -5 ; fibroadenoma -14 ; cyst -16 ; abscess -1 ; fibrolipoma -2 ; intraductal papilloma - 1; the focus of chronic inflammation -1 . The sizes of benign tumors ranged from 0.08 to $6.00 \mathrm{~cm}$ (average size $3.40 \mathrm{~cm}$ ).

In benign processes, vascularization was observed in 14 cases ( $21.5 \%$ of all benign neoplasms), of which 5 fibroadenomas had arterial blood supply, 6 cysts,

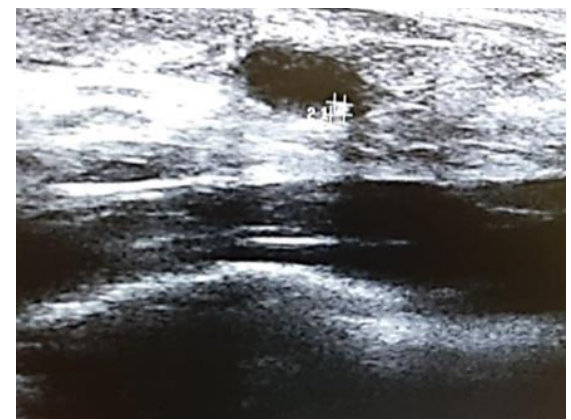

a
1 intraductal papilloma, 1 area of sclerosing adenosis, 1 area of benign breast dysplasia, containing small multiple cysts with thick contents.
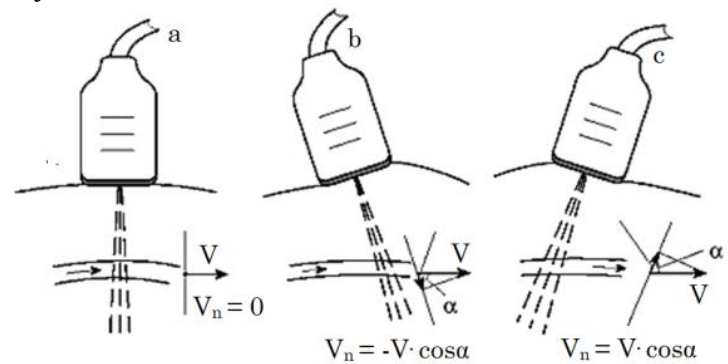

Fig. 3 - Scheme to explain the blood flow velocity in the vessels for different angles of sensor inclination to the axis of the blood vessel

Evaluation of blood flow based on sonograms showed the following results: from 2 to 4 enveloping vessels with a maximum blood flow velocity $V_{\max }=3.0-10.6 \mathrm{~cm} / \mathrm{s}$ (mean value $6.8 \mathrm{~cm} / \mathrm{s}$ ). The minimum blood flow velocity $V_{\min }$ in fibroadenoma arteries ranged from 0.6 to $3.0 \mathrm{~cm} / \mathrm{s}$ (mean value $2.28 \mathrm{~cm} / \mathrm{s}$ ). All cysts, 5 fibroadenomas, fibrolipoma, abscess, cystadenopapilloma were avascular.

Fig. 4 shows examples of sonograms that visualize changes in tissues under the influence of focused ultrasound radiation in the standard two-dimensional mode (mode B) and using the Doppler effect (mode D).

The results show that color Doppler mapping in the differential diagnosis of breast neoplasms with $100 \%$ confidence helped in the case of simple cysts that were avascular. 5 fibroadenomas were avascular, 6 had vessels, bending around a benign formation, with a rather low blood flow velocity (up to $11.0 \mathrm{~cm} / \mathrm{s}$ ).

In sclerosing adenosis, the assessment of blood flow was not diagnostically significant both in grayscale mode and in Doppler examination, which justified the need for further examination of the patient with other diagnostic methods (mammography) and biopsy.

\section{CONCLUSIONS}

1. Physical and biological processes in biological tissues under the influence of ultrasound are considered.

2. It is shown that the reflection and absorption coefficients of ultrasound by soft tissues depend on their structure, properties and frequency of oscillations.

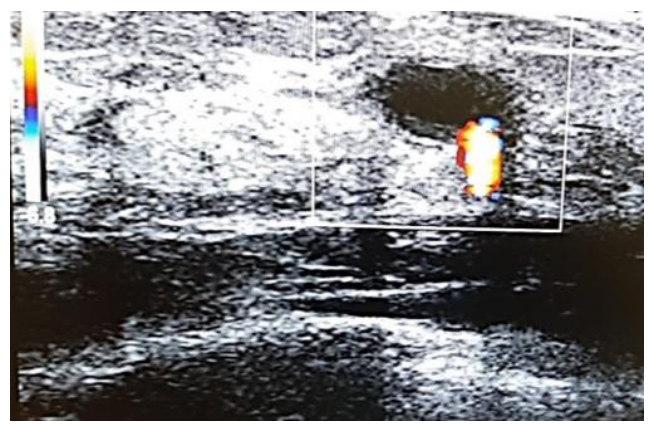

$\mathrm{b}$ 


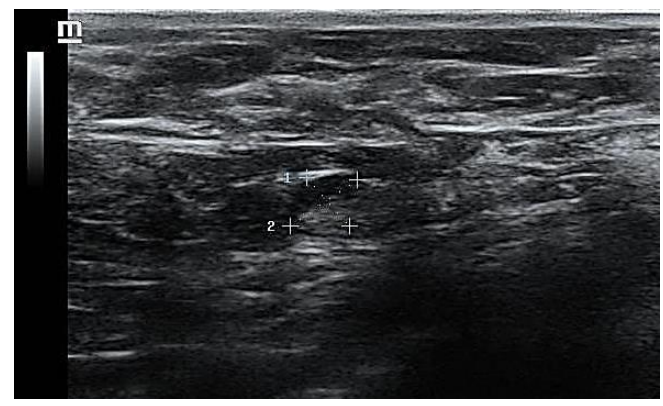

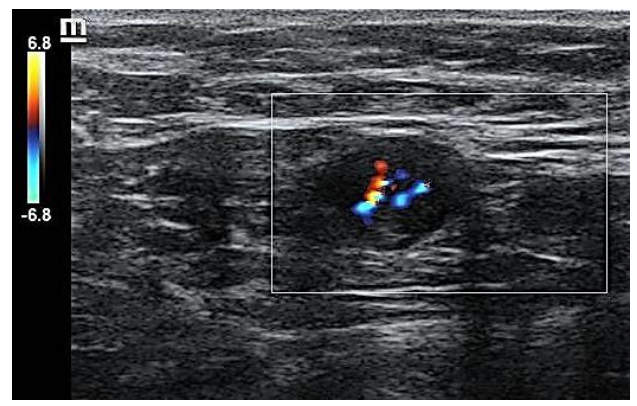

d

Fig. 4 - Diagnostic visualization of changes in breast tissue in the form of cysts (a, b) and lymph nodes (c, d) using ultrasonic waves: a, c - B-mode of operation (2D, two-dimensional); b, d - D-mode of operation (color flow Doppler imaging). The color shows different blood flow velocities: from blue (minimum) to yellow (maximum)

3. Based on sonograms obtained using the Doppler effect, the assessment of blood flow velocity is performed. It is obtained that the blood flow velocity in benign breast tumors has a value from 0.6 to $3.0 \mathrm{~cm} / \mathrm{s}$ (minimum value) and from 3.0 to $10.6 \mathrm{~cm} / \mathrm{s}$ (maximum value).

4. It is proved that the method of color Doppler mapping in the diagnosis of neoplasms gives a completely reliable result in case of cysts and an unreliable result in sclerosing adenosis.

\title{
REFERENCES
}

1. Z. Izadifar, P. Babyn, D. Chapmanz, Ultrasound in Medicine \& Biology 43 No 6, 1085 (2017).

2. V.R. Drier, M. Yao, C.J. Miller, Wound Rep. Reg. 19, 475 (2011).

3. L.V. Odnodvorets, I.Yu. Protsenko, O.P. Tkach, Yu.M. Shabelnyk, N.I. Shumakova, J. Nano- Electron. Phys. 9 No 2, 02021 (2017).

4. R.L. Nichols, S. Florman, Clin. Infect. Dis. 33 No 2, 84 (2001).

5. Stanley B. Barnett, Hans-Dieter Rott, Gail R. ter Haar, Marvin C. Ziskin, Kazuo Maeda, Ultrasound in Medicine \& Biology 23 No 6, 805 (1997).9

6. I.M. Lukavenko, V.V. Andryushchenko, A.V. Yazykov, J. Nano- Electron. Phys. 11 No 3, 03008 (2019).

7. I.M. Lukavenko, J. Nano- Electron. Phys. 11 No 6, 06015 (2019).

\section{Діагностична візуалізація змін в біологічних тканинах ультразвуковим методом на основі ефекту Допплера}

\author{
I.М. Лукавенко, I.А. Симоненко
}

Сулський державний університет, вул. Рилського-Корсакова, 2, 40007 Сули, Україна

\begin{abstract}
Вивчені фрізичні процеси впливу ультразвукових хвиль на біологічні тканини. Показано, що відбиття і поглинання ультразвуку тканинами залежить від їх структури, властивостей і частоти ультразвукових коливань. Коефіціент поглинання ультразвуку суттево змінюеться при зміні структури $\mathrm{i}$ стану тканини в зв'язку з розвитком в ній патологічного процесу. Ультразвук при терапевтичному впливі на тканину викликае механічний, тепловий і фрізико-хімічний ефекти, співвідношення між якими залежить від інтенсивності дії та зовнішніх умов. Встановлено, що сильне поглинання ультразвуку спостерігається на межі тканин, які мають різні акустичні властивості. Розглянуто механізми впливу ультразвукових хвиль на м'які біологічні тканини. На основі сонограм, отриманих в ультразвукових апаратах з використанням ефекту Допплера, проведена оцінка швидкості кровотоку в доброякісних пухлинах. Отримано, що швидкість кровотоку в доброякісних новоутвореннях грудної залози мае величину від 0,6 до 0,3 см/с (мінімальне значення) та від 3,0 до 10,6 см/с (максимальне значення). Доведено, що метод кольорового допплерівського картування в діагностиці новоутворень дає повністю достовірний результат у випадку кіст та малодостовірний результат при склерозуючому аденозі.
\end{abstract}

Ключові слова: Ультразвукові хвилі, Ефект Допплера, Сонограми, Швидкість кровотоку. 